\title{
Developing a sustainable forest management planning system for private woodlots using the Canadian Standards Association Protocol
}

\author{
by Brian Belyea
}

The S.N.B. Woodlot Owner Organizations are in the process of developing a Sustainable Forest Management Plan for the approximately 400,000 ha of productive forest land owned by more than 6000 woodlot owners in southern New Brunswick.

The Canadian Standards Association Protocol is being used as the guiding document in this process. S.N.B. is nearly mid-way through the process with a tentative schedule and target of 15 February 1997 to have the first draft of the system ready for review, approval and implementation by 1 April 1997.

The experience continues to be one of many challenges, not only for the woodlot owner organizations and the woodlot owners themselves, but for the many other stakeholders who have been or will be provided the opportunity to participate. The CSA Protocol provides one of the first frame-works for all the players to "walk their talk" in the real management of a real forest with everyone's interests being facilitated. It also provides the players with the opportunity to demonstrate that they do know what they are talking about and to share that understanding with others to achieve the balances required within sustainable limits.

The CSA Protocol provides challenges in itself. Staying "true to the process" may be the secret to addressing those challenges. In this presentation we shall examine these challenges more specifically.
Les organisations de propriétaires de boisés du sud du NouveauBrunswick sont en voie d'élaborer un plan d'aménagement durable des forêts pour une superficie de près de 400000 ha de boisés privés détenus par plus de 6000 propriétaires de boisés privés du sud du Nouveau Brunswick.

Le protocole de l'Association canadienne de normalisation est utilisé en tant que document de référence pour ce processus. Le regroupement des organisations a complété presque la moitié du processus tout en visant pour le moment le 15 février 1997 comme date de remise du rapport préliminaire sur le système pour fin de révision, l'approbation et la mise en place devant se faire le 1 avril 1997.

Cette initiative comporte par elle-même plusieurs défis, non seulement pour les organisations et pour les propriétaires de boisés privés eux-mêmes, mais pour toutes les personnes impliquées qui ont eu ou qui auront la possibilité d'y participer. Le protocole de la CSA constitue l'un des premiers cadres de référence pour tous les joueurs permettant de "transposer les mots en action" relativement à un aménagement réel d'une forêt réelle en tenant compte des intérêts de tous et chacun. Le protocole permet également aux joueurs de faire preuve qu'ils savent de quoi ils parlent et de partager cette compréhension mutuelle pour atteindre un équilibre adéquat au sein de limites durables.

Le protocole de la CSA représente en soi un défi. Savoir "maintenir la vérité au cours du processus" constitue probablement l'élément-clé permettant de faire face aux défis. Au cours de cette présentation nous examinerons plus en détail ces défis.
The challenge of forest sustainability first presented itself in 1992 as S.N.B. became a partner in the Fundy Model Forest. The partnership represented a broad spectrum of organizations; environmentalists, industrial landowners, government agencies, researchers, recreationalists, ecologists, economists, wildlife biologists and forest managers. An education in the depth and breadth of the sustainability issues facing our forest resource base was quickly attained from the concerns expressed by this partnership. As the issues were examined in pursuit of solutions, their complexity increased beyond S.N.B.'s previous perception of sustainable growing, harvesting and marketing of forest products for a large constituency of individual woodlot owners.

During that same period, woodlot owners in the S.N.B. area were faced with a much shorter-term sustainability issue; the markets for forest products had collapsed and the challenge of the day was in terms of economic survival of the woodlot owner and the S.N.B. organization. In this light, the long term issues of sustainability had much less significance.

P. O. Box 137, Sussex, New Brunswick, Canada E0E 1P0.
As the markets rebounded in 1993, the demand for forest products from private woodlots increased, prices soared, and species never before marketable were in demand. Initially, this was viewed as a short-term market boom that would subside as quickly as it had occurred. However, demand and prices continued to soar to levels never before experienced well into 1993, 1994 and further into 1995. Harvest levels in 1990, 1991 and 1992 had been under the S.N.B. Allowable Annual Cut (AAC). However, in 1993, 1994 and 1995 the AAC was being exceeded by as much as $30 \%$ with no visible indication of a significant turn down. Although S.N.B. had the ability to calculate the $\mathrm{AAC}$ and the co-operation from industry to monitor the harvest levels, no one had the authority to manage the collective purchasing levels for the region. Not only were local mills purchasing at record levels, but mills from northern New Brunswick and Maine were aggressively reaching into the S.N.B. area to obtain wood supplies. Mills were purchasing as much as they could entice woodlot owners to sell at record prices, thereby driving the harvest levels to unprecedented levels. An update of S.N.B.'s wood supply analysis in 1995 indicated that at this pace, within 12 years there would be no mature softwood to be found on S.N.B. woodlots. In 25 years there would be no 
immature softwood trees larger than $12 \mathrm{~cm}$ in stump diameter left on S.N.B. woodlots. Even a turn down in market demand within a few years will have an adverse impact on S.N.B's relatively well balanced age class structure. That impact could take several rotations to rebalance, if possible at all.

Realizing that the purchasing levels driving the harvesting levels were not sustainable, and that harvesting levels have the biggest single impact on our forests, any hope of maintaining wildlife habitat, biodiversity, socio-economic benefits, eco-system balance, forest productivity or any other values were threatened as well.

Further to this, the public was expressing their dissatisfaction with the increase in visible "ugly clear-cuts" on private woodlots. Indiscrete harvesting practices were increasing at alarming rates. The export of wood to out of province manufacturing facilities was threatening employment at local mills. Government silviculture funding, for which we were dependent upon to enhance S.N.B.'s AAC, was being slashed.

Suddenly "Sustainability" was an issue to be addressed immediately as the situation was being compared to the recent collapse of the Atlantic cod fishing industry. Public and government pressure was threatening to initiate legislation to control the management practices on private woodlots if we could not solve the problems ourselves. The issues and problems were complex and political.

In the fall of 1995, S.N.B. received the latest draft of the Canadian Standards Association (CSA) protocol for sustainable Forest Management (SFM) Planning. Previous drafts had been scantly reviewed with pessimism as being too much of an ideology designed to support a short term marketing gimmick, to facilitate the consumer "fad" for certified forest products. However, being desperate to find a solution to the sustainability of our woodlot resources, S.N.B. was challenged to examine this frame-work in a positive perspective to see if they could provide some solution.

The physical reading of $Z 808$ and $Z 809$ was a challenge in itself. They certainly were not prepared in a language considered "user friendly" for a woodlot owner or forest manager. Fortunately, S.N.B.'s introduction and education to the terminology and issues at the Fundy Model Forest provided the ability to perceive the content of the documents. The format of the protocol had to be unscrambled to sort out the value criterion from the process theory and the technical requirements.

From a woodlot owner perspective, the protocol to be followed to develop an SFM System appeared to go far beyond the protective bounds of the woodlot and infringed upon the sacred rights of an owner to do what, when and where he wanted, subject to only his own personal values, objectives and criteria. However, it was apparent that these protective bounds would be infringed upon by society and government eventually if solutions were not found. Although wood supply issues had dominated the S.N.B. organizations attention, it was realized that when expressed in simpler terms than: biodiversity, socio-economics, eco-system condition and productivity, soil and water conservation, global ecological cycles, and social responsibilities, these were all values of importance to woodlot owners throughout the S.N.B. area. Overall, given the diverse demographics and objectives of woodlot owners in southern New Brunswick, the protocol appeared to accommodate everything for everyone. It appeared to provide a frame-work for sorting out the complex problems in a logical process towards achieving an end result that was desirable, if not absolutely necessary. Furthermore, it allowed for the process to occur locally.

It was concluded that SFM Planning at the regional level, supported by appropriate implementation mechanisms at the woodlot level, provided some hope for addressing the issues of the present and those that might arise in the future. But, the question was whether S.N.B. had a sufficient degree of understanding of the process and ability to address the protocol and proceed to implement an SFM Planning Process. A timely opportunity arose to answer these questions as CSA, through the Canadian Federation of Woodlot Owners, solicited proposals from woodlot owner organizations across Canada to test the protocol in a real woodlot owner defined forest area. Their objective was to determine if the protocol was operationally feasible, cost affordable and auditable. S.N.B. successfully applied to be chosen as the test site. In February 1996, the audit team from Levac \& Associes arrived and the testing exercise was undertaken. The result was that the auditors felt the protocol generally met their criteria and S.N.B. felt confident that they did have the degree of understanding required and could accept the challenge of developing an SFM Plan.

The next challenge was to review the CSA protocol again; to develop an action plan which would detail the steps required by translating the philosophical protocol into a strategic planning process appropriate for application in the S.N.B. area, a real forest community. From this, time-frames and budgets could be developed.

The Action Plan was designed in six basic components following the frame-work outlined by the protocol. The components each present a multitude of challenges within themselves some of which are as follows:

\section{1) Commitment Component}

For an organization with a constituency of more than 6000 private landowners to undertake the development of SFM vision, mission, guiding principles, policy statements, statements of responsibilities and commitment requirements has been no doubt, a challenge, but it was accomplished. The challenge ahead will be even greater, to be able to live by and operate by our own commitments. This is often "easier said than done".

\section{2) Public Participation Component - Phase I}

For any private property owner to open their doors to the scrutiny of others and provide opportunity to be told what to do, is a challenge. To be strong enough to accept whatever is received as constructive, in a fair and transparent process, is a challenge. To accept the values and goals of others is a challenge. To explain the Canadian Council of Forest Ministers (CCFM) Criteria and Indicators is a challenge (if the authors of this document feel that they do truly reflect the public's values, then they should be challenged to re-write it in terminology that the public understands).

\section{3) Preparation Component}

Once the public input had been received, the challenge of what to do with it is much greater than obtaining it. How to facilitate so much into a plan and system to please everyone is difficult. The greatest challenge will be for the participants in the process to be able to identify realistic, available indicators and acceptable objective levels for us, as forest managers, to use to fulfil their desires for values. Has the research community 
provided us with the tools to allow us to facilitate their needs? Are the various participants willing to compromise amongst themselves where trade-offs are required? Can they tell us how to manage to achieve each of their specific values and goals?

\section{4) Planning Component}

The challenge here is to pull together all of our technical ability to synchronize the available tools and develop the mechanisms which will produce the maximum sustainable effects, in theory and practice, in a real forest community. This will be the point of truth in our quest to plan for sustainability; the realization of what tools we actually have, their limitations and what can or cannot be performed with them in terms of Sustainable Forest Management today.

\section{5) Public Participation Component - Phase II}

Returning to the public with the realistic results of the planning process may be a disappointing or rewarding challenge. This component, not the accreditation audit, will be the true test of the success of the planning process. Getting public support for the many details, objective levels, strategies, practices, mechanisms and procedures will provide exponential opportunities for dissatisfaction if negatism exists. Conversely, if the public accepts the SFM Plan and Implementation System, albeit less than perfect, this will be tremendously rewarding.

\section{6) Implementation, Review and Improvement}

The challenge here can be simply stated: "after talking all the talk, can we all walk the walk?" This applies not only to S.N.B. and Woodlot Owners, but to the many participants seeking specific values, for they have a role and responsibility in the implementation process as well.

In conclusion, the development of a Sustainable Forest Management Planning system for private woodlots by S.N.B., using the CSA protocol has been and appears as if it will continue to be challenging, yet rewarding. Whether or not this frame-work is perfect or acceptable to everyone as an SFM Certification Process remains to be seen. However, from our perspective, it is a very timely and appropriate framework to address our situation. 